\title{
Nerve Growth Factor Is a Potent Inducer of Proliferation and Neuronal Differentiation for Adult Rat Chromaffin Cells in vitro
}

\author{
Arthur S. Tischler, ${ }^{1}$ Jocelyn C. Riseberg, ${ }^{1}$ Mitchell A. Hardenbrook, ${ }^{1}$ and Van Cherington ${ }^{1,2,3}$ \\ Departments of ${ }^{1}$ Pathology, ${ }^{2}$ Physiology, and ${ }^{3}$ Anatomy and Cellular Biology, Tufts University School of Medicine, Boston, \\ Massachusetts 02111
}

\begin{abstract}
Adult rat chromaffin cells in vitro show a large proliferative response to NGF, followed by neuronal differentiation. Infection of replicating chromaffin cells with a retrovirus carrying the Escherichia coli $\beta$-galactosidase ( $\beta$-gal) gene demonstrates $\beta$-gal expression in cells that continue to multiply, that differentiate into neurons, and that become static. The effects of NGF on proliferation and differentiation are abolished by the protein kinase inhibitors K252a and staurosporine, and by cholera toxin, an activator of adenylate cyclase. They are diminished, but not abolished, by high concentrations of dexamethasone. Both cholera toxin alone and phorbol myristate acetate (PMA), an activator of protein kinase $C$, elicit small and inconsistent mitogenic responses. The responses to PMA cannot be shown to be additive with the effects of NGF. NGF is a known mitogen and neuritogen for chromaffin cells from neonatal rats, but has not previously been believed to affect similarly chromaffin cells from adults. The present findings suggest that portions of NGF signaling pathways might continue to be involved in regulating proliferation of adult rat chromaffin cells in vivo, and might be constitutively activated in PC12 cells and other adrenal medullary tumors. They further suggest that rat chromaffin cells might be propagated in vitro to obtain large numbers of sympathetic neurons expressing normal or exogenous genes.

[Key words: chromaffin cell, NGF, proliferation, neurites, rat, adult, cell culture, bromodeoxyuridine]
\end{abstract}

Rat adrenal chromaffin cells proliferate in vivo throughout life (Malvaldi et al., 1968), and it has recently been shown that their proliferation is regulated by external signals (Tischler et al., 1989). Unilateral adrenal denervation causes a marked decrease in incorporation of bromodeoxyuridine (BrdU) into replicating chromaffin cell nuclei in adult rats (Tischler et al., 1991 b), while reserpine, which reflexly increases synaptic stimulation of chromaffin cells via the splanchnic nerve (Thoenen et al., 1969; Sietzen et al., 1987), causes a marked increase (Tischler et al., 1989). These findings suggest that neurotransmitters and other messengers might continuously regulate chromaffin cell number

Received June 22, 1992; revised Oct. 2, 1992; accepted Oct. 14, 1992

This research was supported by NIH Grants CA 48017 (A.S.T.) and CA 44761 (V.C.). Portions of the work utilized facilities funded by the Digestive Disease Center (NIH P30 DK34928). We thank Miss Lisa Hansbury for secretarial assistance and Dr. Ronald DeLellis for comments on the manuscript.

Correspondence should be addressed to Arthur S. Tischler, M.D., Department of Pathology, Tufts University School of Medicine, 136 Harrison Avenue, Boston, MA 02111.

Copyright (C) 1993 Society for Neuroscience $0270-6474 / 93 / 131533-10 \$ 05.00 / 0$ in response to altered physiological needs. The present investigation was undertaken to begin to characterize in vitro the signaling pathways by which such regulation might be mediated.

During gestation and in the perinatal period, immature rat chromaffin cells in vitro are known to both proliferate and extend neurites in response to fibroblast growth factor (FGF) (Claude et al., 1988; Stemple et al., 1988) and NGF (Unsicker et al., 1978). High concentrations of dexamethasone (dex), which mimic the steroid-rich environment of the adrenal gland, inhibit both proliferation (Lillien and Claude, 1985a) and neuronal differentiation (Unsicker et al., 1978; Doupe et al., 1985) induced by NGF and inhibit neuronal differentiation, but not proliferation, induced by FGF (Claude et al., 1988; Stemple et al., 1988). These findings have led to the suggestion that locally produced FGF-like factors during development might initially expand populations of sympathoadrenal cells, which subsequently respond to NGF in developing ganglia but not in the adrenal (Stemple et al., 1988). Responsiveness of rat chromaffin cells to NGF is not currently thought to persist in adult life. Although the precise timetable for alteration of NGF responsiveness has never been defined, a previous study from our own laboratory showed no NGF-induced neurite outgrowth in chromaffin cells cultured from rats at the age of 3 months (Tischler et al., 1982). The effects of FGF in the adult adrenal are also unknown.

Rat chromaffin cells become functionally innervated after the first postnatal week (Slotkin et al., 1980). Thereafter, cholinergic and/or peptidergic signals stimulate the secretion of catecholamines and other substances (Slotkin et al., 1980), and the replenishment of depleted cellular stores (Sietzen et al., 1987). A possible role for innervation in also regulating chromaffin cell proliferation was first suggested by Ross et al. (1983). Herman et al. (1991) have shown that phorbol myristate acetate (PMA), which activates protein kinase $\mathrm{C}(\mathrm{PKC})$ and thus partially mimics muscarinic cholinergic signaling (Malhotra et al., 1989), also mimics the mitogenic and neuritogenic effects of NGF on chromaffin cells derived from 8 -d-old rats. This finding suggests that muscarinic stimulation might supersede NGF as a chromaffin cell mitogen in adults, possibly by utilizing part of the same signaling pathway. In contrast to PMA, cholera toxin, which activates adenylate cyclase and thus partially mimics peptide neurotransmitters in the rat adrenal (Tischler et al., 1985), antagonizes the neuritogenic effects of NGF (Ziegler and Unsicker, 1981). Although cholera toxin is a mitogen for some types of normal cells derived from the neural crest, both alone and in concert with PMA (Eisinger and Marko, 1982), its effects on chromaffin cell proliferation have not been described. Other agents that increase intracellular CAMP, including the peptide neurotransmitter vasoactive intestinal peptide, have been re- 
ported to be mitogenic for sympathetic neuroblasts (Pincus et al., 1990).

In this investigation, we have assessed the effects of NGF, FGF, and other peptide growth factors on proliferation and differentiation of adult rat chromaffin cells, and have evaluated the interactions of these agents with dex, PMA, and cholera toxin.

Portions of the data have been presented in abstract form at the Sixth International Symposium on Chromaffin Cell Biology (Marburg, Germany, August 1991) and at the 1992 meeting of the U.S. and Canadian Division of the International Academy of Pathology (Tischler, 1992).

\section{Materials and Methods}

Cell preparation. Adrenal medullary cells were obtained by minor modifications of our previously reported technique (Tischler et al., 1982), from 6-9-month-old female Fischer-344 rats (Taconic Farms, Germantown, NY) that were retired breeders. Medullary tissue dissected out of halved adrenal glands was incubated at $37^{\circ} \mathrm{C}$ for $1 \mathrm{hr}$ with gentle rocking in collagenase A (Boehringer Mannheim, Indianapolis, IN) [1.5 $\mathrm{mg} / \mathrm{ml}$ in Hank's balanced salt solution (HBSS)]. The intact tissue fragments were then allowed to settle and were gently transferred to $0.125 \%$ trypsin in calcium- and magnesium-free HBSS. This transfer served to remove debris and residual cortical cells dislodged in the collagenase. After an additional $0.5 \mathrm{hr}$ incubation, the fragments were triturated in a Pasteur pipette to obtain complete dissociation. The trypsin was then inactivated by dilution in an equal volume of RPMI 1640 medium containing $10 \%$ heat-inactivated horse serum (HS), $5 \%$ fetal bovine serum (FBS), penicillin $(40 \mathrm{mg} / \mathrm{ml})$, and streptomycin $(50 \mathrm{U} / \mathrm{ml})$. The suspension was centrifuged at $500 \times g$ for $5 \mathrm{~min}$, and the cells were resuspended in a fresh portion of the above medium, which was used for all experiments unless otherwise specified. Usual yields of chromaffin cells were approximately $150,000-300,000$ per adrenal, comprising 50$70 \%$ of the total cell yield. Percentages of chromaffin cells were estimated in cytocentrifuge preparations by immunocytochemical staining for tyrosine hydroxylase (TH) or in suspension by size and refractility, which was found to be equivalent. To perform some experiments, the cell populations were further purified to obtain greater than $95 \%$ chromaffin cells by one or more rounds of differential detachment after maintenance for at least $24 \mathrm{hr}$ in vilro, as described by Lillien and Claude (1985a).

Experimental procedures. Cells were plated at densities of $1-4 \times 10^{4}$ chromaffin cells/dish in $35 \mathrm{~mm}$ tissue culture dishes coated with airdried rat tail collagen (Bornstein, 1958). Cultures were maintained for up to 4 weeks in control medium or in medium supplemented with varied concentrations and combinations of basic FGF (recombinant human bFGF, Bachem, Torrance, CA), NGF (2.5S mouse salivary gland NGF prepared as described by Mobley et al., 1976; or recombinant human NGF from Austral Biologicals, San Ramon, CA), cholera toxin (List Laboratories, Campbell, CA), PMA (Sigma Chemical Co., St. Louis, $\mathrm{MO}$ ), and dexamethasone (dexamethasone disodium phosphate, a gift from Merck, Sharp and Dohme Research Laboratories, West Point, PA). Other growth factors tested were epidermal growth factor (EGF) (Collaborative Research, Waltham, MA), transforming growth factor $\beta_{1}$ (TGF $\left.\beta_{1}\right)$ (R\&D Systems, Minneapolis, $M N$ ), brain-derived neurotrophic factor (BDNF), and neurotrophin 3 (NT3). (Recombinant human BDNF and recombinant human NT3 were a gift from Drs. Eugene Burton and Karoly Nicolics at Genentech, South San Francisco, CA, and Dr. David Kaplan at the National Cancer Institute.) NGF-containing cultures were further studied in the presence of a neutralizing anti-NGF (Boehringer Mannheim), K252a or staurosporine (50 or 100 nM; Kyowa Hakko, USA, New York, NY), and cytosine arabinoside (ara-C; $1 \mu \mathrm{M}$; Sigma). K252a and staurosporine are protein kinase inhibitors that block most or all of the effects of NGF in cultures of PC12 pheochromocytoma cells (Koizumi et al., 1988; Hashimoto and Hagino, 1989). K252a exerts its inhibitory effects at the NGF receptor kinase (Omichi et al., 1992; Tapley et al., 1992), while staurosporine also appears to act at sites downstream of the receptor, including PKC (Herman et al., 1992). At certain concentrations, including the concentration tested, staurosporine also mimics neuritogenic and other effects of NGF on PC12 cells (Hashimoto and Hagino, 1989; Tischler et al., 1990a, 1991a). Ara-C is an antimitotic agent that was present in the culture medium in previous studies of the neuritogenic effects of NGF on adult rat chromaffin cells (Tischler et al., 1982). Cultures were maintained at $37^{\circ} \mathrm{C}$ in a water-saturated atmosphere of $95 \%$ air and $5 \% \mathrm{CO}_{2}$, with routine medium changes three times per week. In some experiments, the culture medium and serum supplements were altered to reproduce culture conditions under which chromaffin cell proliferation is studied in other laboratories (Lillien and Claude, 1985; Claude et al., 1988; Herman et al., 1991) or to evaluate the effects of reduced serum concentrations on responses to growth factors.

To study the proliferation of chromaffin cells under different experimental conditions, cultures were pulsed at various intervals with bromodeoxyuridine (BrdU; $10 \mu \mathrm{M}$; Sigma), which is incorporated into replicating DNA in place of thymidine (Gratzner, 1982). To confirm that chromaffin cells labeled with BrdU go on to divide, at the time of addition of BrdU some cultures were also supplemented with colcemid $(0.5 \mu \mathrm{g} / \mathrm{ml}$; GIBCO, Grand Island, NY) to arrest dividing cells in mitosis.

After incubation for up to $24 \mathrm{hr}$ with BrdU or BrdU plus colcemid, cultures were fixed sequentially for $10 \mathrm{~min}$ each in $90 \%$ ethanol and $4 \%$ paraformaldehyde and were stained immunocytochemically for BrdU and TH using alkaline phosphatase reporter systems for both antigens, as previously described (Tischler et al., 1992). A black chromogen (alkaline phosphatase black, Vector Laboratories, Burlingame, CA) was used to identify BrdU-labeled nuclei and a pink chromogen (Histomark red, Kirkegaard and Perry, Gaithersburg, MD) to identify TH. To determine whether chromaffin cells that incorporate BrdU under different conditions are epinephrine (E) or norepinephrine (NE) cells, in some experiments cultures were also stained for phenylethanolamine- $N$ methyltransferase (PNMT), the enzyme that synthesizes E from NE. This third antigen was demonstrated using a peroxidase reporter system, with minor modifications of a procedure that we have described (Tischler et al., 1991c). After completion of BrdU staining, the cultures were immersed for $45 \mathrm{~min}$ at room temperature in a solution of $10 \%$ normal goat serum (NGS), $5 \%$ bovine serum albumin (BSA), and $1 \%$ nonfat dry milk in phosphate-buffered saline (PBS), and then incubated overnight at $4^{\circ} \mathrm{C}$ in rat liver-adsorbed (Tischler et al., 1990b) rabbit antiPNMT (INCSTAR Corp., Stillwater, MN; $1: 1000$ in PBS with 1\% NGS and $0.3 \%$ Triton $\mathrm{X}-100$ ). The anti-PNMT was deleted or replaced with normal rabbit serum in cultures that served as immunocytochemical controls. This was followed by incubation for $45 \mathrm{~min}$ at room temperature in biotinylated goat anti-rabbit IgG (Vector Laboratories) $(1: 200$ in PBS with $1 \%$ NGS, $1 \%$ nonfat dry milk, and $0.5 \% \mathrm{BSA}$ ) and $30 \mathrm{~min}$ in avidin-biotin-peroxidase complex from a Vector Laboratories $\mathrm{ABC}$ Elite Kit. A peroxidase reaction product was developed by incubation for approximately $5 \mathrm{~min}$ in a freshly prepared solution of diaminobenzidine $(0.5 \mathrm{mg} / \mathrm{ml})$ and $\mathrm{H}_{2} \mathrm{O}_{2}(0.0001 \% \mathrm{v} / \mathrm{v})$ in $0.1 \mathrm{M}$ Tris buffer, $\mathrm{pH} 7.6$, and this was followed by completion of staining for $\mathrm{TH}$, as previously described (Tischler et al., 1992). This procedure caused E-type chromaffin cells to appear brown and NE-type cells to appear pink. BrdU labeling was quantitated by placing stained dishes on a mechanical stage of a light microscope and visually scoring consecutively scanned chromaffin cells for the presence or absence of black nuclear staining. Labeling indices for all experiments were calculated as percentage \pm standard error of percentage, derived from $n$ of approximately 200 or 300 cells counted for each data point.

Two additional studies were conducted to evaluate further the fate of chromaffin cells that are stimulated to replicate. To study short-term events, adrenal medullary cultures were maintained for $6 \mathrm{~d}$ in medium supplemented with NGF $(50 \mathrm{ng} / \mathrm{ml})$. Chromaffin cells were then purified by differential detachment, replated with NGF in collagen-coated dishes for 2 additional days, and infected with a recombinant retrovirus ("BAG"; Price et al., 1987) encoding Escherichia coli $\beta$-galactosidase ( $\beta$-gal) as a marker gene. The chromaffin cells were exposed over a period of $11 \mathrm{hr}$ to three medium changes with freshly conditioned medium from psi-2 BAG producer cells that had been adapted to grow in RPMI 1640 medium with $10 \%$ HS and 5\% FBS. During each infection cycle, the medium continued to contain NGF, and was also supplemented with Polybrene $(8 \mu \mathrm{g} / \mathrm{ml})$. After the final cycle, the cultures were returned to fresh medium containing NGF. After $2-5$ additional days, they were fixed in $4 \%$ paraformaldehyde in PBS, and cells expressing $\beta$-gal were detected by incubation with $\mathrm{x}$-gal, a chromogenic substrate (Price et al., 1987). Some cultures were then stained immunocy tochemically to demonstrate $\mathrm{TH}$, as described above. To study longer-term events, purified cells were plated with NGF in triplicate dishes without collagen and were repeatedly dislodged at 3-5 dintervals over a period of 3 weeks. At each time point, aliquots corresponding to $10 \%$ of the cell number 


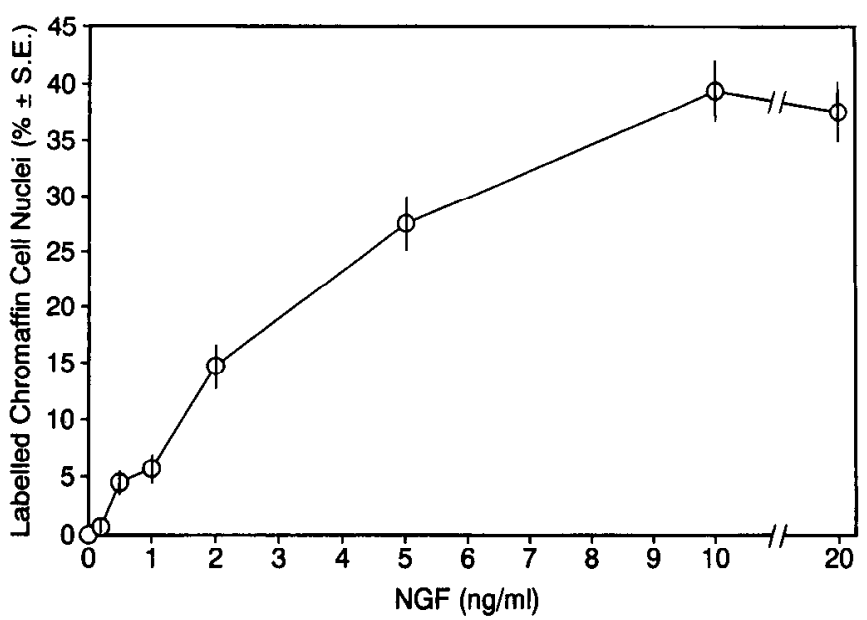

Figure 1. Dose-response curve for the effect of recombinant human NGF on labeling of chromaffin cells with BrdU. Cultures were maintained for $3 \mathrm{~d}$ with the indicated concentrations of NGF, and then pulsed overnight with BrdU and fixed on day 4.

from each dish were centrifuged and resuspended in a cell lysing solution that leaves nuclei intact (Soto and Sonnenschein, 1985). The nuclei were counted in a hemacytometer, and the remainder of the cells were replated. After 3 weeks, all of the cells were trypsinized and replated on collagen-coated dishes to evaluate morphology and NGF dependence. The latter was quantitated by strip counts (Greene, 1977) of surviving cells at intervals after removal of NGF from the medium. Five identified parallel strips comprising approximately $7 \%$ of the area of $35 \mathrm{~mm}$ culture dishes were scanned.

\section{Results}

NGF is a potent mitogen for adult rat chromaffin cells

After a lag period of 24-36 hr, NGF dramatically stimulated incorporation of BrdU into chromaffin cell nuclei. Saturating concentrations of NGF resulted in labeling indices of $25-45 \%$ after an overnight BrdU pulse. Purified chromaffin cells responded to NGF similarly to those in mixed cultures. Recombinant NGF was effective at a half-maximal concentration of

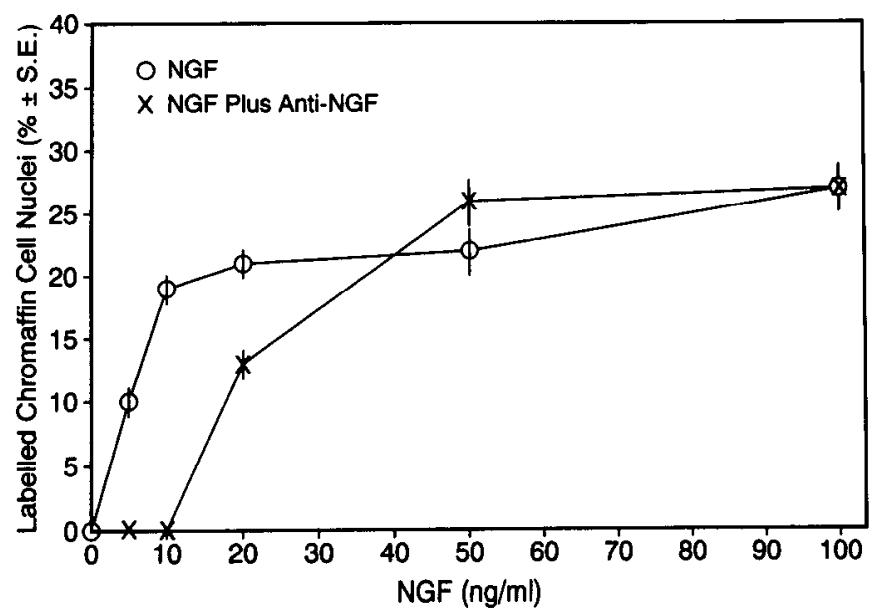

Figure 2. Dose-response curves for the effect of mouse salivary gland NGF on labeling of chromaffin cells with BrdU in the presence or absence of a monoclonal anti-NGF $(200 \mathrm{ng} / \mathrm{ml})$. Cultures were maintained as indicated for $3 \mathrm{~d}$, and then pulsed overnight with BrdU and fixed on day 4.

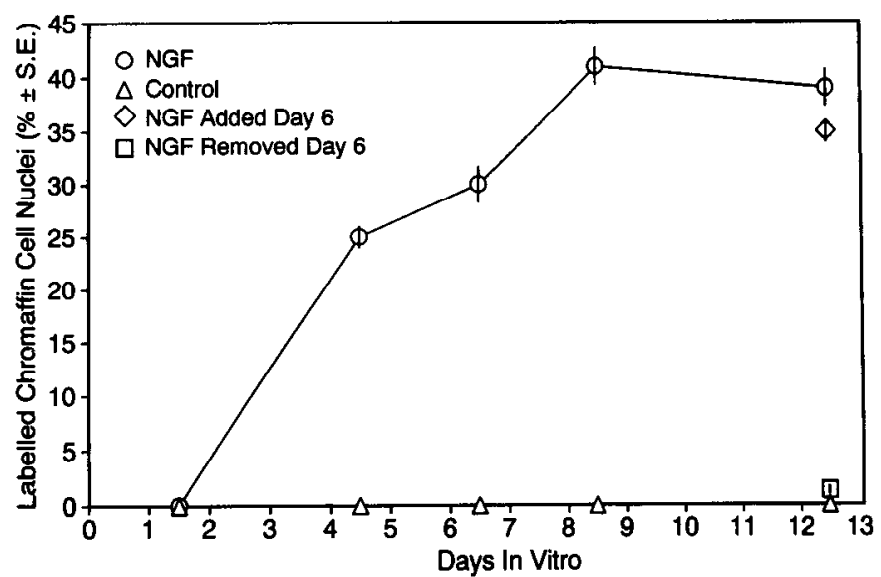

Figure 3. Time course for mitogenic effects of mouse salivary gland $\mathrm{NGF}(100 \mathrm{ng} / \mathrm{nl})$ added to cultures at the time of plating. Cultures were maintained for the indicated number of days, and then pulsed overnight with BrdU and fixed the following morning. The first point therefore represents labeling accumulated over the period from approximately 24-36 $\mathrm{h}$ in vitro.

approximately $5 \mathrm{ng} / \mathrm{ml}$ (Fig. 1). Mouse salivary gland NGF was somewhat less potent, with a half-maximal effect at about 10 $\mathrm{ng} / \mathrm{ml}$ (Fig. 2). Anti-NGF inhibited the effect of subsaturating concentratioins of mouse NGF, but at the concentration tested could not prevent the effect of a large NGF excess (Fig. 2). The percentage of chromaffin cells that incorporated BrdU in response to NGF reached a plateau after 1 week and continued for at least an additional week (Fig. 3). Quantitation of labeling of attached cells, however, became impossible toward the end of the second week because of the presence of large cell clumps. Counts of dispersed nuclei from lysed cells propagated and serially replated in the presence of NGF showed approximately a 2.5 -fold increase in cell number between day $3\left(18 \times 10^{3}\right.$ cells/ dish) and day $11\left(42 \pm 3 \times 10^{3}\right.$ cells $/$ dish, $n=3$ dishes, $p=$ $<0.01$ ), followed by little or no further increase. Chromaffin cells to which NGF was added near the end of 1 or 2 weeks in vitro showed NGF responses comparable to those exposed to NGF at the time of plating, including a comparable lag period

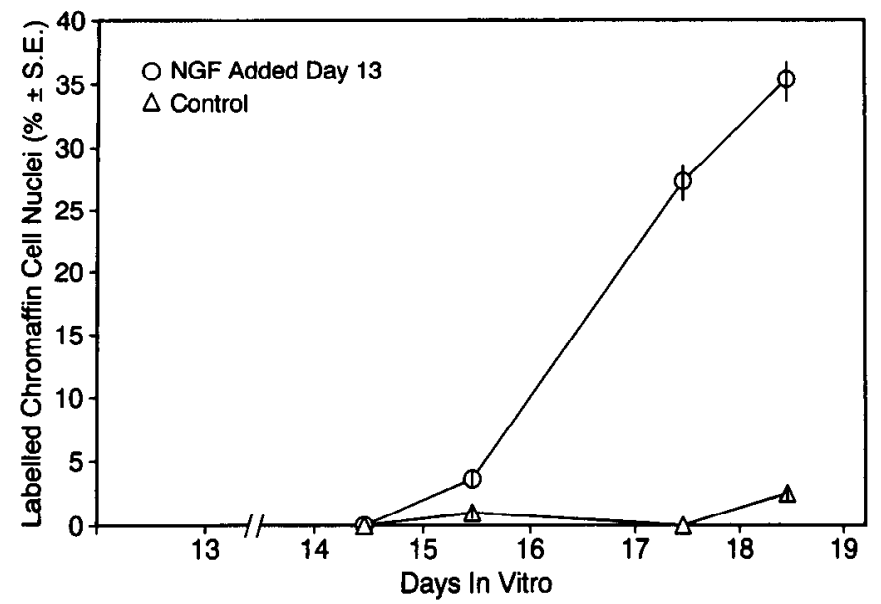

Figure 4. Time course for mitogenic effects of mouse salivary gland NGF $(50 \mathrm{ng} / \mathrm{nl})$ NGF added to cultures after $13 \mathrm{~d}$ in control medium. The cultures were pulsed overnight with BrdU at the end of the indicated subsequent days and fixed on the following mornings. 
A

B

?
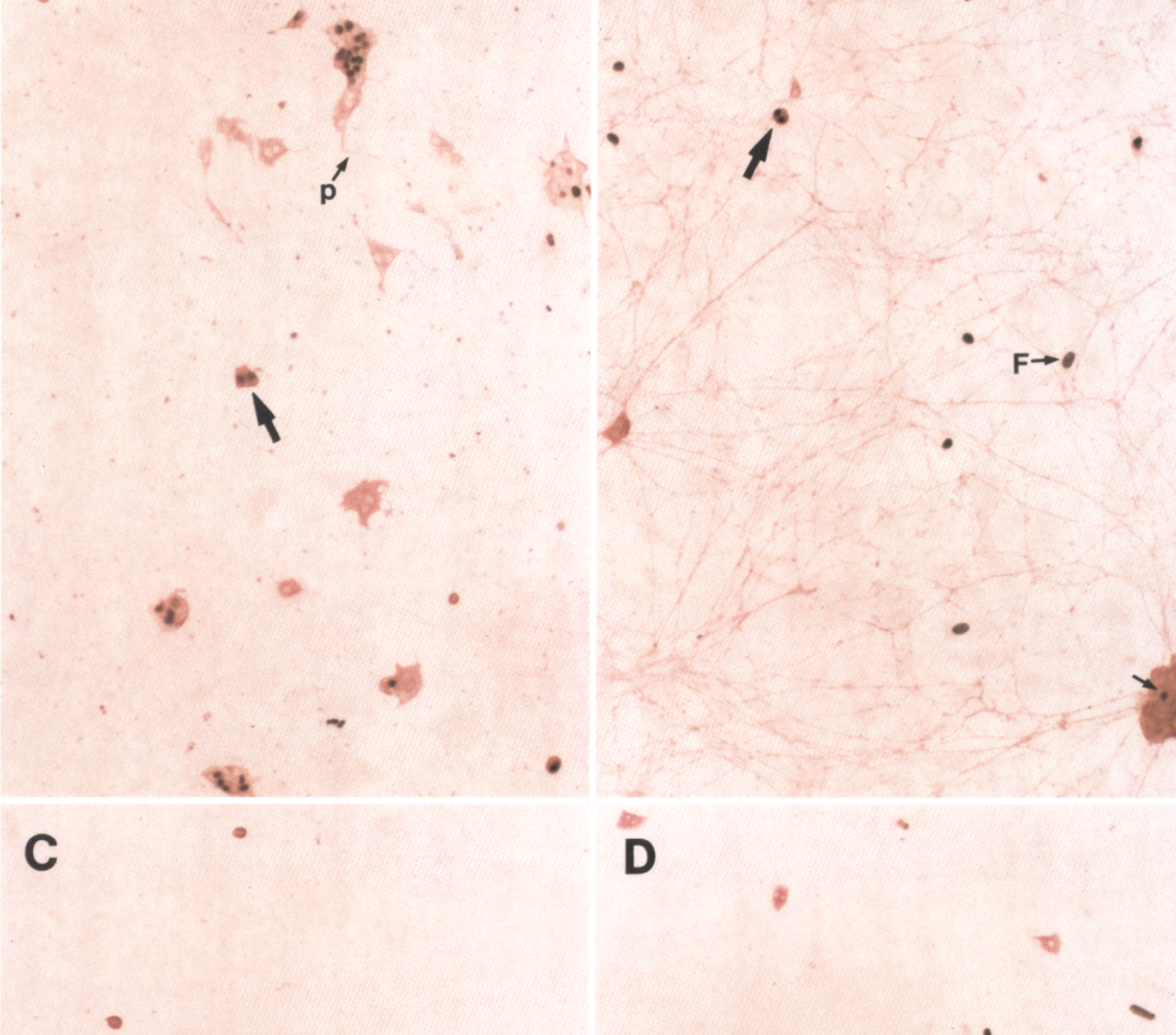

D
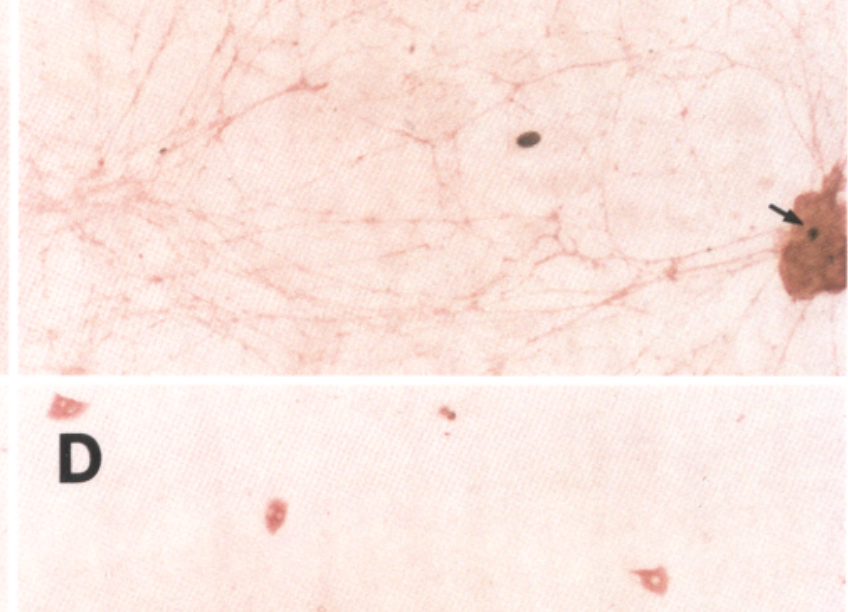

$$
\mathrm{F} \rightarrow
$$

a.

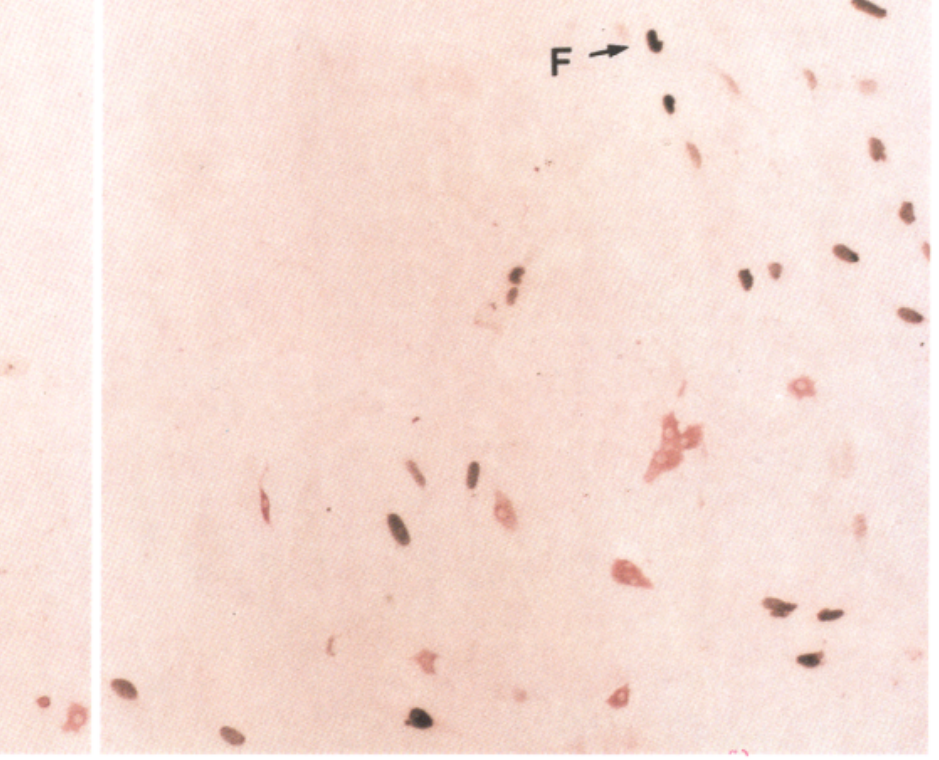


Table 1. Influences of dex and staurosporine on the mitogenic effect of NGF

\begin{tabular}{llc} 
& \multicolumn{2}{c}{ Labeled chromaffin cell nuclei $(\% \pm \mathrm{SE})$} \\
\cline { 2 - 3 } & Experiment 1 & Experiment 2 \\
\hline Control & 0 & $0.7 \pm 0.5$ \\
NGF $(50 \mathrm{ng} / \mathrm{ml})$ & $33.3 \pm 2.7$ & $31.0 \pm 2.7$ \\
NGF+ & + dex $(10 \mu \mathrm{M})$ & + Staurosporine $(50 \mathrm{nM})$ \\
& $16.7 \pm 2.1$ & $1.7 \pm 0.6$
\end{tabular}

Cells were pulsed overnight with BrdU after $3 \mathrm{~d}$ under the indicated conditions and were fixed on day 4.

(Figs. 3, 4). The mitogenic effect of NGF was reversible (Fig. 3).

Nuclei labeled with BrdU were observed both in PNMTpositive and PNMT-negative chromaffin cells maintained with NGF, roughly in proportion to the frequency with which the two cell types occurred, suggesting that NGF does not selectively stimulate E or NE cells (Figs. 5, 6A). Occasional BrdU-labeled mitotic figures (usually less than $1 \%$ of the labeled chromaffin cells) were observed in cultures with or without added colcemid after an overnight pulse with BrdU. After $24 \mathrm{hr}$ with BrdU plus colcemid, chromaffin cells with labeled mitoses were numerous, showing that large numbers of cells that incorporate BrdU ultimately go on to divide (Fig. 6C).

Chromaffin cell cultures that were infected with the BAG virus and then fixed after $2 \mathrm{~d}$ to assess the number of cells infected by using $\beta$-gal activity as a marker showed $\beta$-gal expression in $5 \pm 2 \%$ of chromaffin cells. These were mostly single cells, either alone or within cell clusters (Fig. $7 A$ ). In contrast, activity was present in at least $90 \%$ of identically infected NIH-3T3 cells (Fig. 7D). Chromaffin cell cultures similarly examined for stable expression, $5 \mathrm{~d}$ after infection, showed activity in $3 \pm 1 \%$ of chromaffin cells. Activity was observed in small colonies of chromaffin cells, in single cells, or in single cells with short processes (Fig. $7 \mathrm{~B}$ ). Since stable incorporation of the BAG provirus was likely to have occurred only in cells that were replicating at the time of infection, these findings suggested that replicating chromaffin cells can continue to proliferate, can form processes, or can arrest their proliferation after infection.

NGF-stimulated labeling of chromaffin cells with BrdU was abolished by both $\mathrm{K} 252 \mathrm{a}$ (100 nM) (Fig. 5D) and staurosporine (50 nM) (Table 1). Neither agent abolished labeling of fibroblastlike cells in the same cultures (Fig. 5D). Labeling was greatly reduced, but not totally eliminated, by dexamethasone $(10 \mu \mathrm{M})$ (Table 1). PMA exerted small and inconsistent mitogenic effects that could not be shown to be additive with those of NGF. Cholera toxin was a potent inhibitor of the effects of NGF (Fig. 8 , Table 2), but itself exerted small and inconsistent mitogenic activity. EGF, bFGF, TGF- $\beta_{1}, \mathrm{BDNF}$, and $\mathrm{NT}_{3}$ exerted no detectable effects (Table 2).

Alterations in the composition of the tissue culture medium or of the type of serum supplementation resulted in only minor changes in proliferative responses of chromaffin cells to NGF (Table 3). Decreased concentrations of serum (RPMI 1640 medium with $1 \%$ or $0.1 \%$ HS and $0.5 \%$ or $0.05 \%$ FBS) greatly reduced or eliminated proliferative responses to NGF (data not shown), and did not induce responsiveness to FGF.

\section{$N G F$ induces neuronal differentiation by adult chromaffin cells}

Occasional chromaffin cells cultured in the presence of NGF began to form short neurites after 1 week in vitro. The population of cells with neurites increased dramatically after the second week, together with the number of cells, and by the third week a dense network of processes emerging from almost every large cell cluster covered the surface of the culture dishes. Cells within the clusters typically became spherical, enlarged to several times the diameter of chromaffin cells, and were virtually indistinguishable from cultured neurons (Figs. 9, 10). In order to evaluate process formation by individual cells, clusters of cells that were propagated and serially replated in NGF for $14 \mathrm{~d}$ were trypsinized, plated on collagen-coated dishes, and maintained with NGF for 1 additional week. This procedure yielded nearly pure cultures of cells that exhibited neuronal morphology (Fig. $10)$.

During the early stages of process outgrowth, overnight labeling with BrdU demonstrated short processes on cells with or without labeled nuclei. After 3 weeks, however, labeling had ceased in almost all cells with processes. Labeling continued in fibroblast-like cells in the same cultures, and in occasional chromaffin cells that appeared to persist despite the presence of NGF (Fig. 5). NGF-induced neurite outgrowth was abolished by K252a and staurosporine, at the same concentrations at which these agents blocked proliferation. Outgrowth was also abolished by ara-C, except for rare neuron-like cells that may have been preexisting neurons (Tischler et al., 1982), suggesting that normal rat chromaffin cells must proliferate before they can differentiate into neurons.

\section{Neurons derived from adult chromaffin cells resemble mature sympathetic neurons}

The process of repeatedly dislodging and replating cells for 3 weeks in the presence of NGF gave rise to compact, spherical cell clusters that did not adhere well to plastic surfaces of tissue culture dishes. When these clusters were trypsinized and replated in collagen-coated dishes, virtually pure populations of cells with neuron-like morphology were obtained (Fig. 10). Removal of NGF from the culture medium was followed by only a $15 \%$ decline in cell number after $72 \mathrm{hr}$.

\footnotetext{
Figure 5. Low-magnification photomicrographs illustrating cultures stained for TH (pink cytoplasm and processes) and BrdU (black nuclei) after being maintained under varied conditions. $A$, NGF, 1 week. Almost all of the cells in the field are chromaffin cells, which are seen singly and in clusters of varying size. Short processes $(p)$ have begun to form on chromaffin cells with both labeled and unlabeled nuclei. Arrow at center indicates a pair of chromaffin cells with labeled nuclei. $B, N G F, 3$ weeks. The surface of the dish is covered with a dense network of processes that stain for TH. Labeling of nuclei in cells that form processes has virtually ceased except for one nucleus within a very large cluster at lower right (small arrow). Labeling persists in occasional fibroblast-like cells in which the cytoplasm is not visible $(F)$ and in one pair of chromaffin cells $($ large arrow), similar to that in $A$. $C$, NGF plus ara-C, 3 weeks. Nuclear labeling is not present in any cells. Rare labeled fibroblast-like cells were present in other fields. Chromaffin cells are sparse and have no processes. $D$, NGF plus K252a (100 nM), 2 weeks. The field is selected to show abundant nuclear labeling of fibroblast-like cells $(F)$. Chromaffin cells have unlabeled nuclei and have no processes. Short spikes that do not further elongate are present on some cells. Scale bar, $100 \mu \mathrm{m}$.
} 


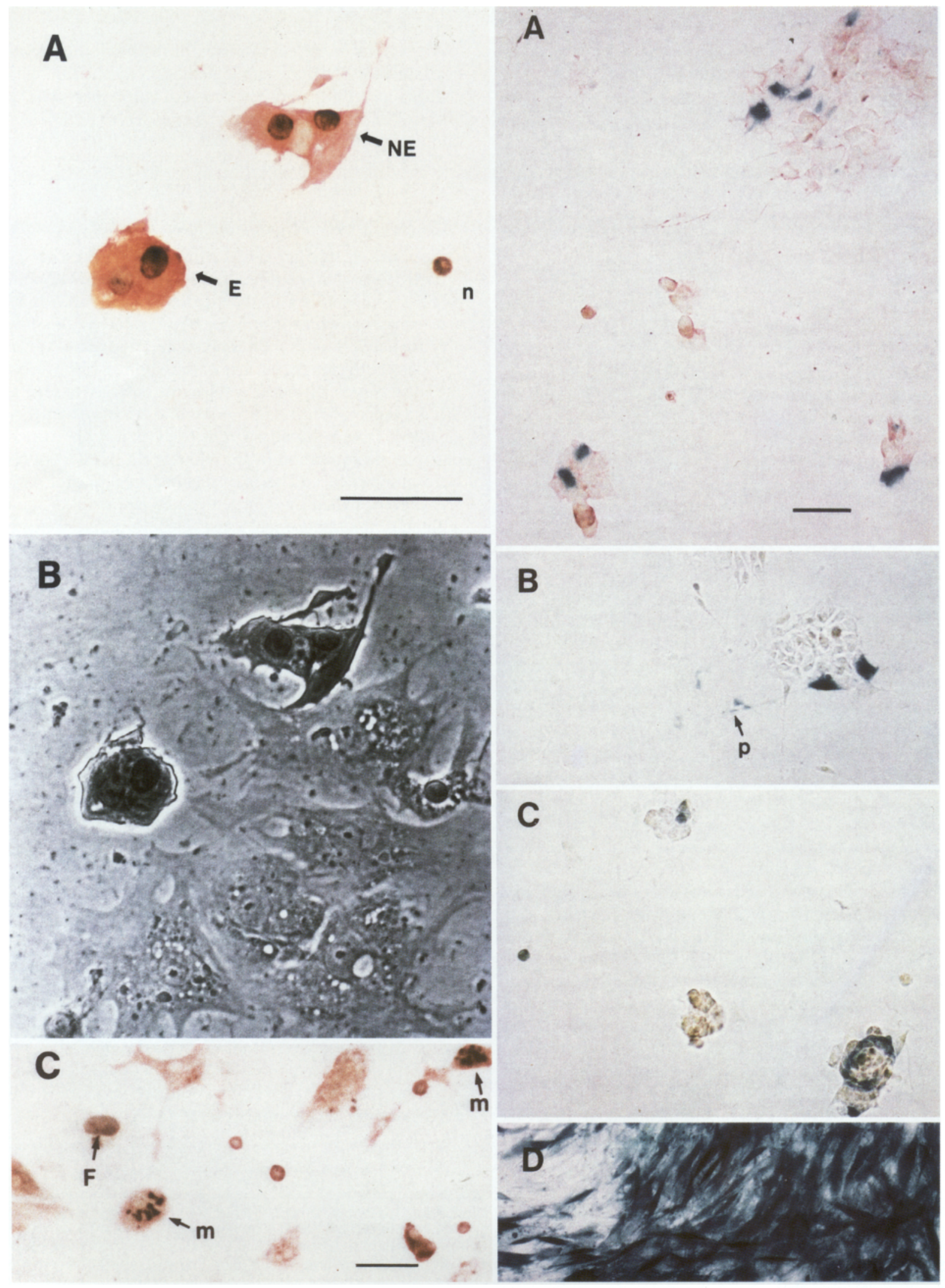

Figure 6. Higher magnification of cytological details of NGF responses in cultures maintained with NGF for $4 \mathrm{~d}$, and then pulsed with BrdU. $A$, Representative chromaffin cells stained for BrdU, TH, and PNMT. Epinephrine-type cells $(E)$ are identified by brown cytoplasmic staining, which masks coexistent pink staining for TH. Norepinephrine-type cells $(N E)$ continue to appear pink. Two NE cells labeled with BrdU and two unlabeled $\mathrm{NE}$ cells are present in the cell cluster at the top of the figure. Two labeled $\mathrm{E}$ cells are present in the smaller cluster. The edge of an unlabeled NE 


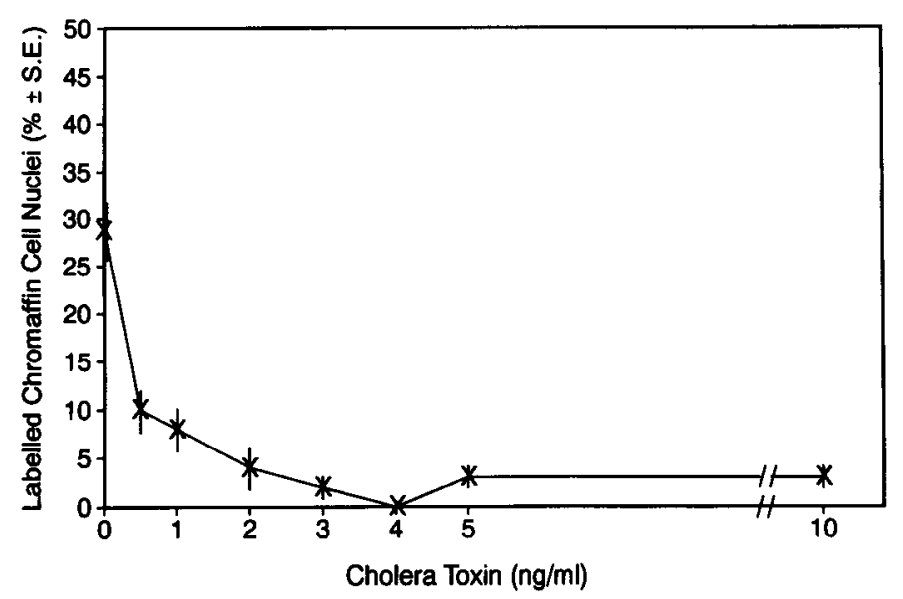

Figure 8. Inhibitory effects of cholera toxin on BrdU labeling stimulated by NGF. Cultures were maintained with mouse salivary gland NGF ( $50 \mathrm{ng} / \mathrm{nl}$ ), plus the indicated concentrations of cholera toxin for $3 \mathrm{~d}$, and then pulsed overnight with BrdU and fixed on day 4 .

\section{Discussion}

We have shown that NGF is a potent mitogen and a potent inducer of neuronal differentiation for normal adult rat chromaffin cells. These findings fill a gap in current concepts of chromaffin cell development, and might provide important insights into both the biology of normal sympathoadrenal cells and the pathobiology of sympathoadrenal tumors. A mitogenic effect of NGF on cells derived from the adrenal medulla was first reported by Burstein and Greene (1982), who isolated subclones of PC12 pheochromocytoma cells for which NGF is mitogenic, rather than antimitogenic as it is for the parent line (Greene and Tischler, 1976). Some investigators subsequently also observed a transient proliferative response to NGF by the parent line (Boonstra et al., 1983). These observations were followed by studies showing that NGF is mitogenic for immature normal chromaffin cells (Lillien and Claude, 1985a), which were already known to undergo neuronal differentiation in response to NGF (Unsicker et al., 1978). However, because adult chromaffin cells, prior to the present investigation, were thought to be unresponsive to NGF, the relevance of the PC12 line to the biology of normal adult chromaffin cells was unclear. Our finding that normal adult chromaffin cells proliferate and differentiate in response to NGF suggests that comparisons between normal chromaffin cells, the parent PC1 2 line, and $\mathrm{PCl} 2$ subclones might help to identify both the normal signaling mechanisms responsible for proliferation and neuronal differentiation, and the ways in which these mechanisms become deranged in neoplasia.

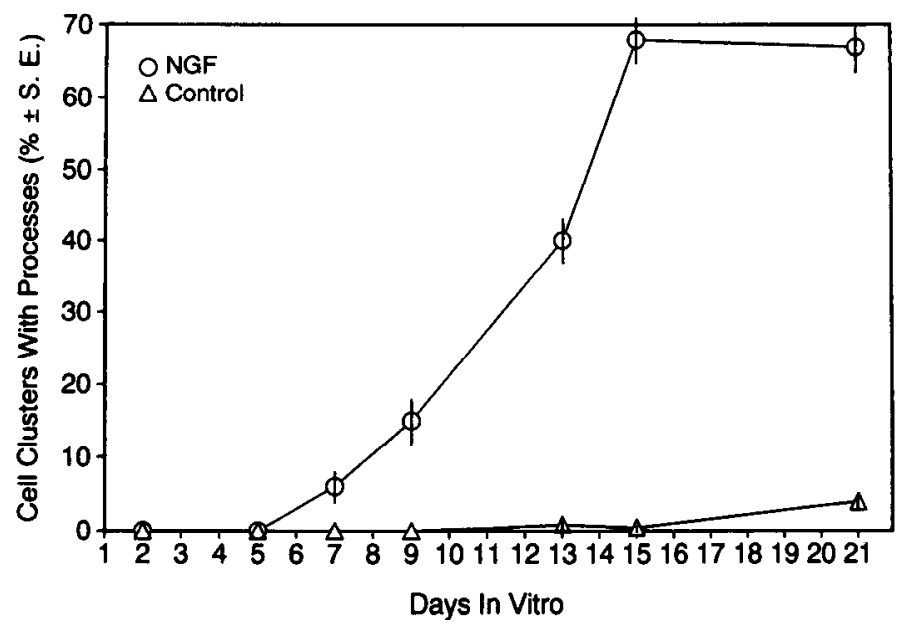

Figure 9. Time course for process outgrowth induced by NGF. Cultures were maintained in the presence or absence of mouse salivary gland NGF $(50 \mathrm{ng} / \mathrm{nl})$ for the indicated number of days, and then pulsed overnight with BrdU and stained for BrdU and TH. Approximately 200 consecutively scanned chromaffin cell clusters were scored for the presence or absence of processes for each point. Because clusters contain individual cells with and without processes, the percentages of clusters with processes are considerably larger than those of individual cells with processes, at least until the last time points (compare Fig. 10). A process was defined as an extension at least 3 cell diameters in length.

The concept that adult rat chromaffin cells do not undergo neuronal differentiation in response to NGF originated with studies in which ara-C was included in the culture medium to prevent overgrowth by fibroblasts (Tischler et al., 1982). When the experiments with ara-C were repeated in the present investigation, nearly complete absence of neuronal differentiation was again observed. Rare neuron-like cells, observed in the presence of ara-C in both the original and present experiments, may have been preexisting neurons or may have originated as chromaffin cells that had divided in vivo before being placed into culture. These findings suggest that the presence of ara-C in the original studies led to an erroneous conclusion about NGF responses. Although the original studies were conducted with male Sprague-Dawley rats and the results reported here were obtained with female F-344 rats, in additional experiments we have observed robust proliferative responses to NGF by chromaffin cells from both male and female Sprague-Dawley rats and from male F-344 rats. However, the possibility of strain-related difference in magnitude of the proliferative response to NGF or in the extent of subsequent neuronal differentiation has not been ruled out.

The mechanism of the inhibitory effects of ara-C on neuronal differentiation is at present unclear. Requirements for prolif-

cell protrudes from the smaller cluster at 11 o'clock. A single labeled nucleus $(n)$ from an unidentified type of small cell is also present. $B$, Phasecontrast photomicrograph of the same field shown in $A$, revealing a small cluster of unlabeled fibroblast-like cells in the background. $C$, Numerous mitotic figures $(m)$ in chromaffin cells maintained for $24 \mathrm{hr}$ in a culture supplemented with both BrdU and colcemid to arrest dividing cells in mitosis and then stained for BrdU and TH. A fibroblast-like cell $(F)$ shows a labeled nucleus but has not entered mitosis. Scale bar, $50 \mu \mathrm{m}$.

Figure 7. Expression of $\beta$-gal activity in cultures infected with the BAG retrovirus. $A$, Clusters of chromaffin cells purified by several cycles of differential detachment over $6 \mathrm{~d}$ in the presence of NGF, and then infected as described and fixed after 2 additional days. Scattered blue cells demonstrating $\beta$-gal activity comprise a small percentage of the total chromaffin cell population. The culture in this panel is stained to demonstrate immunoreactive TH in addition to $\beta$-gal. $B$ and $C$, Replicate dishes demonstrating $\beta$-gal activity $5 \mathrm{~d}$ after infection. Activity is present in a cell with a short blue process $(p$ in $B$ ), in cells that have apparently proliferated within a cell cluster (lower right, $C$ ), and in single cells that resemble those in $A$. D. NIH-3T3 cells infected concurrently with the chromaffin cells shown in $A-C$ and fixed after day 2 . Scale bar, $50 \mu \mathrm{m}$. 

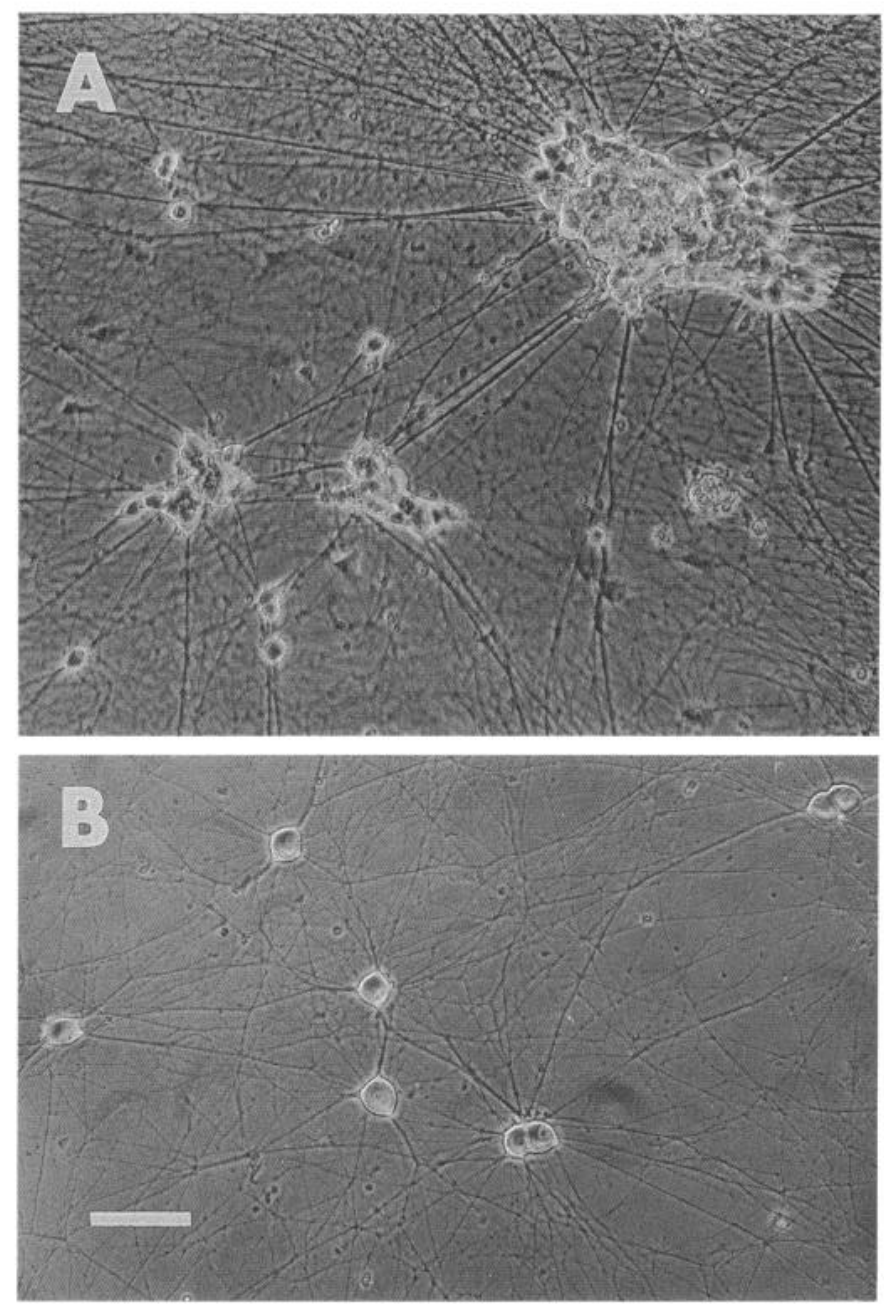

Figure 10. Phase-contrast photographs comparing long-term effects of mouse salivary gland NGF $(50 \mathrm{ng} / \mathrm{ml})$ on adrenal medullary populations maintained by different culture methods. $A$, Cells maintained with NGF for 3 weeks after plating on a collagen substrate. $B$, Cells purified by repeated cycles of differential detachment from a plastic culture dish during 3 weeks in the presence of NGF, and then trypsinized, plated on collagen, and maintained with NGF for 1 additional week. Scale bar, $100 \mu \mathrm{m}$. eration as a prelude to terminal differentiation have been described for other cell types, and in some instances involve welldefined signaling events (Ailhaud et al., 1990). However, the relationship in the nervous system is controversial (Harris and Hartenstein, 1991). Doupe et al. (1985) reported that NGFinduced neurite outgrowth is not inhibited in cultures of immature chromaffin cells exposed to cobalt 60 irradiation or to transient combined treatment with ara-C plus other antimetabolites. It might, however, be argued that immature chromaffin cells are actually proliferating in vitro before being exposed to NGF. In additional preliminary studies of adult chromaffin cell cultures irradiated as described by Doupe et al. (1985), we have observed very little inhibition of neurite outgrowth, but have also noted incomplete inhibition of NGF-stimulated BrdU labeling (approximately $10 \%$ of labeling persisting in two separate experiments after overnight pulses with BrdU). Additional studies are therefoie required to determine whether the continuous presence of ara-C inhibits neurite outgrowth through toxicity or through specific mechanisms related to inhibition of proliferation. It may be of interest that a major difference between normal rat chromaffin cells and $\mathrm{PC} 12$ cells is that inhibiting proliferation of PC12 cells with ara-C does not prevent neuronal differentiation (Dichter et al., 1977). Since NGF exerts large mitogenic effects on normal chromaffin cells before promoting neurite outgrowth, it is intriguing to speculate that a portion of the NGF signaling pathway related to cell proliferation might be constitutively activated in PC12 cells and might be implicated in the process of neoplastic transformation. Normal adult primate chromaffin cells clearly extend neurites without proliferating (Lillien and Claude, 1985b), but differences might exist between primates and rats in that respect.

In contrast to the effects of NGF, proliferative responses to PMA or cholera toxin detectable with the same duration of BrdU labeling were small and inconsistent. The possibility that these effects were indirect and mediated by contaminating cell types has not been ruled out. However, the percentages of labeled cells observed in cultures stimulated by PMA and cholera toxin are similar to those observed in adults rats in vivo with a comparable duration of labeling (Tischler et al., 1989). It has been shown that longer durations of labeling in vivo with lower concentrations of BrdU, administered by osmotic minipumps,

Table 2. Interactions of NGF and other growth factors with cholera toxin and PMA

\begin{tabular}{lclll} 
& \multicolumn{3}{c}{ Labeled chromaffin cell nuclei $(\% \pm \mathrm{SE})$} \\
\cline { 2 - 5 } & No additions & $\begin{array}{l}\text { Cholera toxin } \\
(10 \mathrm{ng} / \mathrm{ml})\end{array}$ & $\begin{array}{l}\text { PMA } \\
(50 \mathrm{nM})\end{array}$ & $\begin{array}{l}\text { Cholera toxin } \\
+ \text { PMA }\end{array}$ \\
\hline No additions & 0 & $1.0 \pm 0.6$ & $3.0 \pm 1.0^{*}$ & $1.0 \pm 0.6$ \\
EGF $(100 \mathrm{ng} / \mathrm{ml})$ & 0 & $0.6 \pm 0.4$ & $4.7 \pm 1.2^{*}$ & $0.3 \pm 0.3$ \\
bFGF $(20 \mathrm{ng} / \mathrm{ml})$ & $0.3 \pm 0.3$ & $2.0 \pm 0.8$ & $2.3 \pm 0.9^{*}$ & 0 \\
TGF- $\beta_{1}(5 \mathrm{ng} / \mathrm{ml})$ & $0.7 \pm 0.5$ & $1.3 \pm 0.6$ & $1.7 \pm 0.8$ & $1.3 \pm 0.7$ \\
NGF $(50 \mathrm{ng} / \mathrm{ml})$ & $26.7 \pm 2.5$ & $1.3 \pm 0.7$ & $17.2 \pm 2.1^{*}$ & 0 \\
Dex $(10 \mu \mathrm{M})$ & & 0 & $0.7 \pm 0.5$ & $2.1 \pm 0.9$
\end{tabular}

Cultures were pulsed overnight with BrdU after $3 \mathrm{~d}$ with the indicated medium supplements and were fixed on day 4. * Statistically significant at $p<0.01$ by $\chi^{2}$ tests comparing numbers of labeled and unlabeled cells to those in control medium with no additives. Values for cholera toxin are not significant in this experiment. However, the same concentration of cholera toxin produced effects comparable to those shown for PMA in two of three additional experiments, while effects of the same concentration of PMA were not significant in three of nine additional experiments. Doseresponse experiments for cholera toxin and PMA showed optimal responses at the indicated concentrations, as also described for PMA by Herman et al. (1991), but reproducible dose-response curves could not be obtained. TGF- $\beta_{1}$, which inhibits cell proliferation in some tissues, neither inhibited nor augmented the response to NGF (33 $\pm 3 \%$ of chromaffin cells labeled in the presence of NGF plus TGF- $\left.\beta_{1}\right)$. BDNF $(20 \mathrm{ng} / \mathrm{ml})$ and NT3 $(20 \mathrm{ng} / \mathrm{ml}) \mathrm{exerted} \mathrm{no}$ detectable effects in two additional experiments. 
Table 3. Influence of medium and serum on the mitogenic effect of NGF



Cells were pulsed overnight with BrdU after $3 \mathrm{~d}$ under the indicated conditions and were fixed on day 4.

results in accumulation of labeled chromaffin cell nuclei (Tischler et al., 1991b). It is therefore likely that modification of the in vitro BrdU labeling protocol in future studies will help to define better the roles of PKC and cAMP in stimulating chromaffin cell proliferation and to elucidate their relationships to the signaling pathways utilized by NGF. Inhibition of the mitogenic effects of NGF by staurosporine is consistent with a role for PKC in stimulating proliferation, as noted by Herman et al. (1991). However, pharmacological dissection of the signaling pathways utilized by NGF is notoriously difficult because of the involvement of multiple kinases (Chao, 1992; Volonté and Greene, 1992) and the overlapping specificities of various inhibitors. One important question that remains to be answered is whether PMA exerts mitogenic effects by upregulating or downregulating PKC. Although chronic exposure to PMA downregulates PKC in PCI2 cells (Matthies et al., 1987), it can cause prolonged elevation of PKC activity in rat sympathetic neurons (Wakade et al., 1988). Morc impressive than the mitogenic effects of either PMA or cholera toxin in the present investigation were the marked inhibition of the NGF effect by cholera toxin and the lesser degree of inhibition by dex. These inhibitory effects suggest that proliferation of chromaffin cells in vivo might normally be subject to both negative and positive controls.

In view of persisting NGF responsiveness of adult chromaffin cells, it is perhaps surprising that we have not also detected persisting responses to FGF. A role for FGF in the adult rat adrenal in vivo is suggested by immunohistochemical studies localizing immunoreactive FGF to a subset of adult chromaffin cells (Grothe and Unsicker, 1990). We have shown that the absence of detectable FGF effects in this investigation was unrelated to the presence of serum in the culture medium. Further, serum does not block the effects of FGF on immature chromaffin cells in vitro (Claudc ct al., 1988; Stemple et al., 1988). Ongoing studies, however, suggest that FGF might exert mitogenic effects on a small percentage of adult chromaffin cells, detectable only after prolonged BrdU labeling.

The results reported here have a number of practical implications, particularly for studies related to chromaffin cell transplantation. First, our findings reconcile neurite outgrowth from adult rat chromaffin cells transplanted to ectopic sites (Olson, 1970) with the lack of neurite outgrowth previously observed in vitro, and they may explain enhancement of graft survival and neurite outgrowth in the presence of NGF (Strömberg et al., 1985). Second, they suggest that it may be possible to easily obtain very pure populations of terminally differentiated, mature, normal sympathetic neurons by propagation and differential detachment of adult chromaffin cells in the presence of NGF. In contrast to immature sympathetic neurons, which die within $48 \mathrm{hr}$ after NGF removal (Chun and Patterson, 1977; Greene, 1977), the ncurons obtained from our chromaffin cell cultures appear to have reduced NGF dependence characteristic of maturity (Johnson, 1983; Ruit et al., 1990). It will be useful to study further the acquisition of this mature trait.

Finally, our experiments with the BAG retrovirus suggest it is possible to exploit proliferation induced by NGF to obtain stable expression of exogenous genes in cells with either chromaffin cell or neuronal phenotypes. The percentage of cells that expressed $\beta$-gal in cultures infected with the BAG retrovirus in these experiments was quite low, even though this type of vector is highly efficient at infecting other cell types. Similarly low efficiency has been reported with PC1 2 cells (Price et al., 1987). The explanation of why chromaffin cells are poor targets for retroviral vectors is at present unclear.

\section{References}

Ailhaud G, Amri EZ, Bardon S, Barcellini-Couget S, Bertrand B, Catalioto R, Dani C, Djian P, Doglio A, Forest C, Gaillard D, Grimaldi P, Negrel R, Vannier C, Vassaux G (1990) The adipocyte: relationships between proliferation and adipose cell differentiation. Am Rev Respir Dis 142:S57-S59.

Boonstra J, Moolenaar WH, Harrison PH, Moed P, van der Saag PI, de Laat SW (1983) Ionic responses and growth stimulation induced by nerve growth factor and epidermal growth factor in rat pheochromocytoma (PC12) cells. J Cell Biol 97:92-98.

Bornstein MB (1958) Reconstituted rat-tail collagen used as a substrate for tissue culture on coverslips on Maximow slides and roller tubes. Lab Invest 7:134-140.

Burstein DE, Greene LA (1982) Nerve growth factor has both mitogenic and anti-mitogenic activity. Dev Biol 94:477-482.

Chao MV (1992) Growth factor signalling-where is the specificity? Cell 68:995-997.

Chun LL, Patterson PH (1977) Role of nerve growth factor in the development of rat sympathetic neurons in vitro. J Cell Biol 75:705711.

Claude P, Parada IM, Gordon KA, D'Amore PA, Wagner JA (1988) Acidic fibroblast growth factor stimulates adrenal chromaffin cells to proliferate and to extend neurites, but is not a long term survival factor. Neuron 1:783-790.

Dichter MA, Greene LA, Tischler AS (1977) Nerve growth factorinduced increase in electrical excitability and acetylcholine sensitivity of a rat pheochromocytoma cell line. Nature 268:501-504.

Doupe AJ, Landis SC, Patterson PH (1985) Environmental influences in the development of neural crest derivatives: glucocorticoids, growth factors and chromaffin cell plasticity. J Neurosci 5:2119-2142.

Eisinger M, Marko O (1982) Selective proliferation of normal human melanocytes in vitro in presence of phorbol ester and cholera toxin. Proc Natl Acad Sci USA 79:2018-2022.

Gratzner HG (1982) Monoclonal antibody to 5-bromo- and 5-iododeoxyuridine: a new reagent for detection of DNA replication. Science 218:474-475.

Greene LA (1977) Quantitative in vitro studies on nerve growth factor (NGF) requirement of neurons. I. Sympathetic neurons. Dev Biol 58: 96-105. 
Greene LA, Tischler AS (1976) Establishment of a noradrenergic clonal line of rat adrenal pheochromocytoma cells which respond to nerve growth factor. Proc Natl Acad Sci USA 73:2424-2428.

Grothe C, Unsicker K (1990) Immunocytochemical mapping of basic fibroblast growth factor in the developing and adult rat adrenal glands. Histochemistry 94:141-147.

Harris WA, Hartenstein V (1991) Neuronal determination without cell division in Xenopus embryos. Neuron 6:499-515.

Hashimoto S, Hagino A (1989) Blockage of nerve growth factor action in $\mathrm{PC} 12$ cells by staurosporine, a potent protein kinase inhibitor. $J$ Neurochem 53:1675-1685.

Herman MA, Schulz CA, Claude PA (1991) Chronic exposure to an activator of protein kinase C mimics early effects of NGF in chromaffin cells. Dev Biol 146:558-568.

Johnson MI (1983) Dissociated neurons from adult rat superior cervical ganglion show reduced NGF requirements in culture. Soc Neurosci Abstr 9:846.

Koizumi S, Contreras ML, Matsuda Y, Hama T, Lazarovici P, Guroff G (1988) K-252a-a specific inhibitor of the action of NGF on PC12 cells. J Neurosci 8:715-721.

Lillien LE, Claude $P$ (1985a) Nerve growth factor is a mitogen for cultured chromaffin cells. Nature 317:632-634.

Lillien LE, Claude P (1985b) Nerve growth factor and glucocorticoids regulate phenotypic expression in cultured chromaffin cells from adult rhesus monkeys. Exp Cell Res 161:255-268.

Malhotra RK, Wakade TD, Wakade AR (1989) Cross communication between acetylcholine and VIP in controlling catecholamine secretion by affecting cAMP, inositol triphosphate, protein kinase $\mathrm{C}$ and calcium in rat adrenal medulla. J Neurosci 9:4150-4157.

Malvaldi G, Mencacci P, Viola-Magni MP (1968) Mitoses in the adrenal medullary cells. Experientia 24:475-477.

Matthies HJG, Palfrey HC, Hirning LD, Miller RJ (1987) Down regulation of protein kinase $C$ in neuronal cells: effects on neurotransmitter release. J Neurosci 7:1198-1206.

Mobley WC, Schenker A, Schooter EM (1976) Characterization and isolation of proteolytically modified nerve growth factor. Biochemistry 15:5543-5551.

Olson L (1970) Fluorescence histochemical evidence for axonal growth and secretion from transplanted adrenal medullary tissue. Histochemie 22:1-7.

Omichi M, Decker SJ, Pang L (1992) Inhibition of the cellular actions of nerve growth factor by staurosporine and K252a results from the attenuation of the activity of the $t r k$ tyrosine kinase. Biochemistry 31:4034-4039.

Pincus DW, DiCicco-Bloom EM, Black IB (1990) Vasoactive intestinal peptide regulation of neuroblast mitosis and survival: role of cAMP. Brain Res 514:355-357.

Price J, Turner D, Cepko C (1987) Lineage analysis in the vertebrate nervous system by retrovirus-mediated gene transfer. Proc Natl Acad Sci USA 84:156-160.

Ross LL, Smolen AJ, McCarthy L (1983) Supraspinal pathways regulate the mitotic activity of adrenal medulla cells. Anat Rec 205:167168.

Ruit KG, Osborne PA, Schmidt RE, Johnson EM Jr, Snider WD (1990) Nerve growth factor regulates sympathetic ganglion cell morphology and survival in the adult mouse. J Neurosci 10:2412-2419.

Sietzen M, Schober M, Fischer-Colbrie R, Scherman D, Sperk G, Winkler H (1987) Rat adrenal medulla. Levels of chromogranins, enkephalins, dopamine-beta-hydroxylase and the amine transporter are changed by nervous activity and hypophysectomy. Neuroscience 22 : 131-139.

Slotkin TA, Smith PG, Lau C, Barsis DL (1980) Functional aspects of development of catecholamine biosynthesis and release in the sym- pathetic nervous system. In: Biogenic amincs in development (Parvez H, Parvez S, eds), pp 29-48. Amsterdam: Elsevier/North Holland.

Soto AM, Sonnenschein C (1985) The role of estrogens on the proliferation of human breast tumor cells (MCG-7). J Steroid Biochem 23:87-94.

Stemple DL, Manthappa NK, Anderson DJ (1988) Basic FGF induces neuronal differentiation, cell division and NGF dependence in chromaffin cells: a sequence of events in sympathetic development. Neuron 1:517-525.

Strömberg IM, Herrera-Marschitz U, Ungerstedt T, Olson L (1985) Chronic implants of chromaffin tissue into the dopamine-denervated striatum. Effects of NGF on graft survival, fiber growth and rotational behavior. Exp Brain Res 60:335-349.

Tapley P, Lamballe F, Barbacid M (1992) K252a is a selective inhibitor of the trk family of oncogenes and neurotrophin receptors. Oncogene 7:371-381.

Thoenen H, Mueller RA, Axelrod J (1969) Trans-synaptic induction of adrenal tyrosine hydroxylase. J Pharmacol Exp Ther 169:249-254.

Tischler AS (1992) Proliferative responses to chromaffin cell mitogens by adult rat and human chromaffin cells in vitro. Lab Invest 66:34A.

Tischler AS, Pearlman RL, Nunnemacher G, Morse GM, DeLellis RA, Wolfe HJ, Sheard BE (1982) Long-term effects of dexamethasone and nerve growth factor on adrenal medullary cells cultured from young adult rats. Cell Tissue Res 225:525-542.

Tischler AS, Perlman RL, Costopoulos D, Horwitz J (1985) Vasoactive intestinal peptide activiates tyrosine hydroxylase in normal and neoplastic chromaffin cells in culture. Neurosci Lett 61:141-146.

Tischler AS, Ruzicka LA, Donahue SR, DeLellis RA (1989) Chromaffin ccll proliferation in the adult rat adrenal medulla. Int $J$ Dev Neurosci 7:439-448.

Tischler AS, Ruzicka LA, Perlman RL (1990a) Mimicry and inhibition of NGF effects: interactions of staurosporine, forskolin and K252a. J Neurochem 55:1159-1165.

Tischler AS, Ruzicka LA, VanPelt CS, Sandusky GE (1990b) Catecholamine-synthesizing enzymes and chromogranin proteins in druginduced proliferative lesions of the rat adrenal medulla. Lab Invest 63:44-51.

Tischler AS, Dobner PA, Ruzicka LA (1991a) A protein kinase inhibitor, staurosporine, mimics nerve growth factor induction of neurotensin/neuromedin N gene expression. J Biol Chem 266:1141-1146.

Tischler AS, McClain MR, Childers H, Downing J (199lb) Neurogenic signals regulate chromaffin cell proliferation and mediate the mitogenic effect of rescrpine in the adult rat adrenal medulla. Lab Invest 65:374-376.

Tischler AS, Ruzicka LA, DeLellis RA (1991c) Regulation of neurotensin content in adrenal medullary cells: comparison of PC12 cells to normal rat chromaffin cells in vitro. Neuroscience 43:671-678.

Tischler AS, Ruzicka LA, Riseberg JC (1992) Immunocytochemical analysis of chromaffin cell proliferation in vitro. J Histochem Cytochem 40:1043-1045.

Unsicker K, Krisch B, Otten U, Thoenen H (1978) Nerve growth factor-induced fiber outgrowth from isolated rat adrenal chromaffin cells: impairment by glucocorticoids. Proc Natl Acad Sci USA 75: 3498-3502.

Volonté C, Greene LA (1992) 6-Methylmercaptopurine riboside is a potent and selective inhibitor of nerve growth factor-activated protein kinase N. J Ncurochem 58:700-708.

Wakade AR, Wakade TD, Malhotra RK, Bhave SV (1988) Excess K+ and phorbol ester activate protein kinase $C$ and support the survival of chick sympathetic neurons in culture. J Neurochem 51:975-983.

Ziegler W, Unsicker K (1981) Differential effects of cyclic AMP and cholera toxin on nerve growth factor-induced neurite outgrowth from adrenal medullary chromaffin and pheochromocytoma cells. Dev Brain Res 1:622-627. 